Website: https://journal.stiba.ac.id

ISSN : 2685-7537 (online) 2338-5251 (Printed)

\title{
JENIS DAN LANGKAH PENELITIAN HADIS
}

\section{Sofyan Nur}

Sekolah Tinggi Ilmu Islam dan Bahasa Arab (STIBA) Makassar,

Jl. Inspeksi PAM Manggala-Antang Makassar

E-Mail: sofyannur@stiba.ac.id

\section{Keywords :}

types, steps and hadiths

\section{ABSTRACT}

Hadits, which is on the second hierarchy of Islamic law, always attracts the scholars to conduct the studies and discussions on it. Lacking of aspects in the study of hadits seems to open a vast space to discuss and study on the hadits. Through exploring the scholars' works in the study of hadits, it is necessary to comprehend that the study of hadits has its own kinds and steps. These steps are the procedures that have to be passed through in the study in accordance with their own kinds. The objective of this study is to provide understanding and guidance in the study of hadits at once, in accordance with the kinds of study of the hadits which has to be passed through. 


\section{PENDAHULUAN}

Hadis merupakan dasar kedua dalah hirarki hukum islam setelah alQur'an. Sebagaiman al-Qur'an, hadīs juga sangat perlu untuk dikaji agar kandungannya yang merupakan petunjuk dan hidayah dapat dipahami dengan baik oleh segenap kaum muslimin.

Dalam kajian hadis yang kemudian disebut dengan penelitian hadis, haruslah mengikuti langkahlangkah yang telah digariskan oleh ulama hadis. Sebab hadis memiliki struktur dan komponen yang agak berbeda dengan al-Qur'an. Suatu hadīs memiliki dua komponen utama, yaitu sanad dan matn hadīs.

Penelitian suatu hadis akan tertuju kepeda keduanya, oleh karena itu haruslah memiliki langkah-langkah yang terstruktur dan sistematis agar menghasilkan hasil penelitan yang benar. Oleh karena itu penelitian hadīs dibagi menjadi dua jenis; sanad dan matan. Masing-masing jenis memiliki langkahnya masing-masing. Dengan demikian sangatlah penting mengurai kedua jenis peneklitian tersebut berikut langkahnya masing-masing.

Dengan demikian penelitian suatu hadīs dapat dilakukan sesuai dengan apa yang digariskan oleh ulama hadīs yang telah menghabiskan hidup mereka demi pengkajian hadīs Nabi sallallabu alaibi wa sallam. sehingga tujuannya pun dapat tercapai berupa tersingkapnya status dan hukum setiap hadīs sahih, hasan atau daif. Lalu setelah itu kandungan setiap hadīs agar dapat diamalkan dalam kehidupan sehari-hari. Topic pembahasan utama dalam makalah ini adalah "Apa Jenis

${ }^{1}$ Muslim bin Hajjāj, Șahīh Muslim (Cet. 1, Kairo, Dār Ibnu al-Jauzī, 2010), h.8. dan Bagaiman Langkah Penelitian Hadis " yang kemudian diturunkan dalam beberapa rumusan masalah, sebagai berikut:

1. Bagaimana pembagiaan penelitian hadis?

2. Bagaimana langkah-langkah penelitian hadis?

\section{PEMBAHASAN}

\section{Pembagian Jenis Penelitian Hadis \\ Menurut strukturnya yang} terdiri dari dua unsure utama yaitu sanad dan matn, maka penelitian hadis akan tertuju kepada kedua unsure tersebut. Inilah yang mendasari pemabagian jenis penelitian suatu hadis. Sehingga dapat dikatakan bahwa penelitian hadīs terbagi dua, penelitian sanad dan penelitian matan hadis.

a. Penelitian Sanad

Ulama hadīs sangat menganggap penting kedudukan sanad dalam suatu hadīs. Karena pentingnya sanad dalam suatu hadīs, maka sutau berita yang dinyatakan sebagai hadīs Nabi oleh seseorang, namaun tidak memiliki sanad, maka berita tersebut oleh ulama hadīs tidak dapat disebut sebagai hadīs.

Pentingnya sanad suatu hadīs dapat dilihat dalam ungkapanungkapan mereka, diantaranya adalah :

Imam Muhammad bin Sirin berkata :" Sesungguhnya ilmu ini adalah bagian dari agama, maka perhatikanlah dari mana kalian mengambil agama kalian". ${ }^{1}$

Berkata Ibnu al-mubārak :" Isnad itu bagian dari agama".

Pernyataan ini menunjukkan bahwa ulama hadīis memandang sanad 
itu sebagai suatu yang sangat penting, bahwa sahihnya sanad suatu hadīis sangat mempengaruhi kualitas hadīis itu sendiri. Sanad bagi mereka adalah bagian dari agama yang harus dijaga dan diperhatikan dengan baik.

Lemahnya suatu sanad hadīis tertentu sebenarnya belumlah menjadikan hadī̇ yang bersangkutan secara absolute tidak berasal dari Rasulullah. Dalam pada itu riwayat hadīs yang sanadnya lemah tidak dapat memberikan bukti yang kuat bahwa hadīs yang bersangkutan berasal dari Rasulullah. Padahal Rasulullah adalah sumber ajaran islam, dan karenanya riwayat hadī $\dot{s}$ haruslah terhindar dari keadaan yang meragukan.

Dalam kenyataan yang dihadapi setiap kali membuka atau membaca suatu hadīis, ada saja hadīs yang sanadnya meragukan dan jumlahnya banyak. Hal ini disebabkan karena banyaknya orang yang terlibat dalam periwayatannya, dengan kualitas yang bermacam-macam.

Menghadapi sanad yang bermacam-macam itu, maka ulama ahli hadīs menyusun berbagai istilah. Selain untuk mempermudah membedakan macam-macam sanad yang keadaannya sangat berfariasi, juga untuk mempermudah penilaian terhadap sanad yang bersangkutan dalam hubungannya dengan dapat atau tidak dapatnya dijadikan hujjah. ${ }^{3}$ diteliti

Bagian-bagian sanad yang

Dalam penelitian sanad hadīis, seorang peneliti harus paham elemen apa saja yang harus diteliti dari sebuah sanad. Ada dua bagian penting yang dapat dilihat:

${ }^{3}$ Syuhudi Ismail, Metodologi Penelitian Hadis Nabi, (Cet.1, Jakarta, Bulan Bintang, 1992 ), h.25.
1. Nama-nama periwayat yang terlibat dalam periwayatan hadìs yang bersangkutan.

2. Lambang-lambang periwayatan hadìs yang telah digunakan oleh masing-masing periwayat dalam meriwayatkan hadīs yang bersangkutan.

Dalam suatu penelitian hadīs yang telah dilakukan oleh ulama ahli hadīis, dapat dilihat secara jelas, bahwa mereka selain berkonsentrasi pada keadaan periwayat dalam sanad itu, perhatian mereka juga tidak lepas dari lambang-lambang periwayatan yang digunakan oleh setiap periwayat dalam satu sanad. Keduanya harus diteliti, sebab illat atau cacat pada suatu hadīs dapat muncul karena kualitas periwayat baik secara pribadi maupun intelektuanya, bisa juga terdeteksi melalui lambing-lambang periwayatan yang digunakan.

\section{b. Penelitian Matan}

Matn hadīis merupakan salah satu unsur pembentuk hadīis, matn hadīis adalah lafadz-lafdz hadīis itu sendiri ${ }^{4}$. Sebagaiman halnya pada sanad, maka matn suatu hadīis juga harus dipastikan, apakah benar berasal dari Rasulullah atau tidak. Oleh karena itu matan hadìs merupakan salah satu obyek penelitian dalam masalah hadīis.

Pentingnya penelitian hadìs bukan hanya karena keadaan matn tidak dapat dilepaskan dari keadaan sanad saja, tetapi juga karena dalam periwayatan matn hadīis dikenal adanya periwayatan dengan makna. Periwayatan dengan makna dapat diterima dengan syarat-syarat yang telah ditetapkan oleh ulama ahli hadīis. Namun tidak semua periwayat yang

4Jalaluddin al-Suyūțī, Tadrīb al-Rāwi (Cet. 1, Riyadh, Dār al-Āșimah, 1424 H ), h.41. 
terlibat dalam periwayatan dengan makna dapat memenuhi syarat-syarat tersebut.

Untuk matan hadīis yang mengandung berita tentang peperangan atau kisah-kisah tertentu, maka penelitian matan tidak perlu dilakukan pada kata perkata, namun bila suatu hadīs mengandung suatu ajaran, perintah atau larangan, maka penelitian matan harus mencakup keadaan setiap kata dalam matn tersebut ${ }^{5}$. Oleh karena itu penelitian hadīis dalam masalah ini merupakan penelitian yang berdasarkan semantic.

Adapun untuk meneliti matan hadīis dari segi kandungannya, maka terkadang diperlukan pendekatan rasio, sejarah dan prinsip-prinsip pokok ajaran islam.dengan demikian kesahihan matan hadīs yang dihasilkan tidak saja dilihat dari sisi bahasa saja, tetapi juga dilihat dari sisi yang mengacu kepada rasio, sejarah dan prinsip-prinsip pokok ajaran islam.

Meskipun penelitian matan hadīis dapat dilakukan dengan berbagai pendekatan, namun tetap saja penelitian matan masih terasa sulit. Betapa tidak, kitab -kitab yang membahas tentang penelitian matan sangat sedikit, berbeda dengan penelitian sanad, dimana kitab-kitab yang membahasnya masih sangat banyak.

Dari pembahsan di atas, dapat dikatakan bahwa kesulitan dalam melakukan penelitian matan hadīis adalah karena beberapa hal :

1. Adanya periwayatan secara makna.

2. Pendekatan yang digunakan dapat bermacam-macam.

${ }^{5}$ Syuhudi Ismail, Metodologi Penelitian Hadis Nabi, h. 26.

${ }^{6}$ Syuhudi Ismail, Metodologi Penelitian Hadis Nabi, h. 28.
3. Latar belakang timbulnya petunjuk hadīs tidak selalu mudah diketahui.

4. Terbatasnya kitab-kitab yang membahas penelitian matan hadìs. ${ }^{6}$

Namun perlu dipahami bahwa, meskipun ada kesulitan dalam penelitian matan, namun dengan mengikuti langkah-langkah yang telah disusun oleh ulama ahli hadīis, maka penelitian matan hadīis dapat dilakukan dan memberikan hasil kualitas matan yang obyektif.

2. Langkah-langkah penelitian hadīis.

Penelitian hadīs bukanlah sesuatu yang terlampau sulit, namun juga tidak mudah, oleh karena itu ulama hadīis telah memberikan langkahlangkah agar penelitian suatu hadīis dapat berjalan dengan baik dan memeberikan hasil yang objektif tentang kualitas suatu hadīis. Adapun langkah-langkah penelitian hadīí adalah sebagai berikut :

a. Takhrij al-Hadīis

Takhrij didefinisikan oleh para ulama dengan banyak definisi yang beragam, namun adapun yang sesuai dengan penelitian hadis adalah menunjukkan atau mengemukakan letak asal hadis pada sumbernya yang asli, yakni berbagai kitab yang di dalamnya dikemukakan hadis-hadis itu secara lengkap dengan sanadnya masing-masing; kemudian ntuk kepentingan penelitian, dijelaskan kualitas hadis yang bersangkutan. ${ }^{7}$

Bagi peneliti hadis proses takhrij al-hadis adalah suatu yang sangat penting.tanpa takhrij al-hadis, akan sulit mengetahui asal-usul hadis yang kemudiankan menyulitkan untuk

${ }^{7}$ Mahmud al-Ṭahhān, Ușūl al-Takhrīj ( Cet.2, Beirut, Dār al-Qur'an al-Karīm, 1979), h.9. 
menelusri ada tidaknya syahi atau mutabi'. Oleh karena itu perlu mengetahui langkah-langkah yang harus diikuti dalam proses takhrij alhadis. Minimal ada tiga hal yang menjadi sebab perlunya takhrij al-hadis:

1. Untuk mengetahui asal-usul riwayat hadis yang akan diteliti.

Suatu hadis akan sangat sulit diteliti status dan kualitasnya bila tidak terlebih dahulu dilakukan takhrij sehingga tidak dapat dilacak asalusulnya.tanpa menegtahui asal-usulnya, sangat sulit menentukan kualitas sanad dan matan hsuatu hadis. Hal tersebut dikarenakan tidak dapatnya menyingkap susunan sanad dan matn karena tidak ketahuan asal-usulnya.

2. Untuk mengetahui seluruh riwayat bagi hadis yang akan diteliti.

Suatu hadis yang akan diteliti bisa saja memiliki lebih dari satu sanad atu jalur periwayatan. Namun bisa juga hanya memilikisatu sanad saja. Mengetahui riwayat hadis atau jalurjalur sanad suatu hadis sangatlah penting. Bisa saja suatu hadis sebagaian sanadnya sahih namun yang lain daif. Keadaan seperti ini sangat berpengaruh pada kualitas sanad itu sendiri bahkan kualitas hadis tersebut.

3. Untuk mengetahui ada atau tidaknya syahid atau mutabi' pada hadis yang diteliti.

Sanad sebuah hadis bisa saja didukung oleh sanad yang lain yang diriwayatkan oleh periwayat yang lain. Dukungan itu bila terletak pada tingkat periwayat tertingggi yaitu sahabat, maka disebut syahid. Sedangkan bila terdapat pada bagian bukan tingkat sahabat maka disebut mutabi'. Syahid atau mutabi' yang memiliki sanad yang kuat, mungkin dapat mendukung dan menaikkan derajat atau kualitas sanad hadis yang diteliti.

Dengan ketiga hal tersebut, jelaslah bahwa dalam sebuah penelitian hadis, proses takhrij merupakan suatu hal yang sangat penting dan harus dilakukan bila ingin mendapatkan hasil penelitian yang maksimal.

\section{b. I'tibar}

Kata I'tibar merupakan masdar dari kata I'tabara (اعتبر). Menururt bahasa arti kata I'tibar adalah peninjauan terhadap berbagai hal dengan maksud untuk dapat diketahui sesuatunya yang sejenis. ${ }^{8}$ Menurut istilah ilmu hadis, al-I'tibar berarti menyertakan sanad-sanad yang lain untuk suatu hadis tertentu, yang hadis itu pada sanadnya tampak hanya seorang periwayat saja; dan dengan menyertakan sanad-sanad yang lain tersebut akan dapat diketahui apakah ada periwayat yang lain ataukah tidak ada untuk bagian sanad dari sanad hadis dimaksud.

Dengan melakukan I'tibar maka akan terlihat dengan jelas seluruh jalur sanad yang diteliti, demikian juga nama-nama periwayatnya dan metode periwayatan yang digunakan oleh masing-masing periwayat yang bersangkutan. Dengan kata lain, I'tibar berfungsi untuk mengetahui keadaan sanad sesungguhnya dilihat dari ada atau tidaknya sanad-sanad pendukung.

c. Meneliti pribadi periwayat

Setelah melakukan I'tibar, maka langkah selanjutnya adalah dengan meneliti pribadi para periwayat hadis, meskipun I'tibar itu sendiri adalah awal dari proses penelitian sanad. Hal ini dialkukan untuk memastikan kesahihan sanad. Secara

${ }^{8}$ Mahmud al-Ṭahhān, Taisīr Musțalah alHadisis ( Cet. 1, Mesir, Dar al-hadis, 1432 H), h. 87. 
operasional yang menjadi dasar dalam masalah ini adalah kaidah kesahihan sanad.

Hal-hal yang perlu diteliti dari seorang periwayat adalah :

1. Kualitas pribadi periwayat

Kualitas periwayat bagi suatu hadis yang sahih adalah bahwa periwayat haruslah adil. Dalam kamus umum bahasa Indonesia dinyatakan bahwa kata adil berarti " tidak berat sebelah ". "

Dalam bahasa arab adl berarti : pertengahan, lurus, atau condong kepada kebenaran. ${ }^{10}$ Namun dalam istilah ulama hadis, adl adalah beragama islam, mukallaf, melaksanakan ketentuan agama dan menjaga muru'ah. ${ }^{11}$ Semua kriteria yang disebutkan dalam definisi tersebut, merupakan sesuatu yang bersifat kumulatif. Seorang periwayat yang memenuhi kriteria hadis sahih haruslah memenuhi semua kriteria tersebut.

2. Kapasitas intelektual periwayat Intelektualitas periwayat haruslah memenuhi kapasitas tertentu sehingga riwayat hadis yang disampaikannya dapat memenuhi salah satu unsure hadis sahih. Periwayat yang memenuhi hal tersebut disebut dengan dābit yang secara bahasa berarti kokoh, kuat,tepat dan yang menghapal dengan sempurna. ${ }^{12}$

Dalam menilai pribadi periwayat ini, ada satu hal yang sangat berpengaruh yaitu ilmu Jarh wa ta'dil. Penilaian terhadap kualitas pribadi periwayat dan kapasitas intelektualnya tidak dapat didapatkan tanpa menggunakan jarh wa ta'dil. Disamping

${ }^{9}$ W.J.S. Purwadarminta, Kamus Umum Bahasa ( Cet. 8, Jakarta, Balai Pustaka, 1985), h.16.

${ }^{10}$ Ibnu Manzūr, Lisan al-Arab (Cet.1, Mesir, al-Dār al-Misriyah, 1427 H), h.456. itu, ilmu jarh wa ta'dil juga ditopang oleh ilmu yang lain, seperti ilmu tabaqat, dan ilmu -ilmu yang lain.

d. Penelitian matn hadis

Unsur kedua dalam suatu hadis adalah matn, hadis yang sahih haruslah merupakan hadis yang sahih sanad dan matnnya. Matn suatu hadis sangat berpengaruh dalam kesahihan suatu hadis. Penelitian matn hadis sangatlah penting, sebab tidak semua sanad yang sahih disertai dengan matn yang sahih pula.

Penelitian matn hadis dapat dilakukan dengan mengikuti langkahlangkah yang telah disebutkan oleh ulama hadis:

1. Meneliti matan dengan melihat kualitas sanadnya.

2. Meneliti susunan lafadz berbagai matn yang semakna.

3. Meneliti kandungan matn. ${ }^{13}$

Dengan mengikuti ketiga langkah tersebut diharapkan segi-segi penting yang harus diteliti pada matn suatu hadis dapat mendatangkan hasil yang dapat dipertanggungjawabkan. Bila dalam penelitian sanad dan matn didapati hasil bahwa sanad suatu hadis sahih, dan matnnya juga sahih, maka hadis tersebut dikatakan sebagai hadis sahih.

\section{PENUTUP}

Dari pembahsan di atas dapat disimpulkan dua hal :

1. Penelitian hadis dapat dibagi menjadi dua hal; penelitian sanad dan penelitian matn.

2. Penelitian hadis dapat dilakukan dengan langkah-

\footnotetext{
${ }^{11}$ Syuhudi ismail, Kaidah Kesahihan Sanad Hadis (Cet.1, Jakarta, Bulan Bintang, 1992),h.113. ${ }^{12}$ Syuhudi ismail, Kaidah Kesahihan Sanad Hadis, h. 122.

${ }^{13}$ Syuhudi Ismail, Metodologi Penelitian Hadis Nabi, h. 122.
} 
langkah berikut; takhrij alhadis, I'tibar, penelitian pribadi periwayat (penelitian sanad) dan penelitian matn hadis.

\section{DAFTAR PUSTAKA}

Ibnu Manzūr, Lisan al-Arab, Cet.1, Mesir, al-Dār al-Misriyah, 1427 $\mathrm{H}$.

Jalaluddin al-Suyūțī, Tadrīb al-Rāwi, Cet. 1, Riyadh, Dār al-Āṣimah, 1424 $\mathrm{H}$.

Mahmud al-Ṭahhān, Taisì Musțalah alHadis, Cet. 1, Mesir, Dar alhadis, $1432 \mathrm{H}$.

Mahmud al-Ṭahhān, Ușūl al-Takhrīj, Cet.2, Beirut, Dār al-Qur'an alKarīm, 1979.

Muslim bin Hajjāi, Sabīh Muslim ,Cet. 1, Kairo, Dār Ibnu al-Jauzī, 2010.

Syuhudi Ismail, Kaidah Kesabihan Sanad Hadis, Cet.1, Jakarta, Bulan Bintang, 1992.

Syuhudi Ismail, Metodologi Penelitian Hadis Nabi, Cet.1, Jakarta, Bulan Bintang, 1992.

W.J.S. Purwadarminta, Kamus Umum Bahasa, Cet. 8, Jakarta, Balai Pustaka, 1985. 